\title{
Preliminary investigation of mineralogy and chemistry of peats from the Kietrz site, southern Poland
}

\author{
Sylwia Skreczko ${ }^{*}$, Weronika Nadłonek², Krzysztof Szopa ${ }^{3}$ \\ ${ }^{1}$ Department of Fundamental Geology, Faculty of Earth Sciences, University of Silesia, Będzińska 60, 41-200 \\ Sosnowiec, Poland, corresponding author: sylwia.skreczko@us.edu.pl \\ ${ }^{2}$ Department of Economic Geology, Faculty of Earth Sciences, University, Będzińska 60, 41-200 Sosnowiec, \\ Poland \\ ${ }^{3}$ Department of Geochemistry, Mineralogy and Petrography, Faculty of Earth Science, University of Silesia, \\ Będzińska Str. 60, 41-200 Sosnowiec,
}

Received: $3^{\text {rd }}$ August, 2015

Accepted: $30^{\text {th }}$ September, 2015

\begin{abstract}
Peat bog deposits provide a very important record of past environmental conditions, preserving biotic and abiotic processes that occurred in the vicinity of the bog. In this study, we examined three peat bog profiles from Kietrz, located in the micro-region of the Głubczycki Plateau, southern Poland.

The objective of this study was to determine the type of peat occurring in this area, through examination of its mineral composition, and evaluation of the total carbon and total sulphur content. In addition, we measured peat reaction $(\mathrm{pH})$ and identified floral and faunal components occurring within the peat deposits.

The peat comprises primarily of fragments of fossilized plant and mollusk remains, as well as minerals (calcium sulphates, calcium carbonates, and pyrites). Additionally, an assemblage of iron oxides/hydroxides, Kfeldspar, apatite, zircon, and quartz grains was identified. A neutral and/or light alkalinity was recorded for the peat deposits, but an increase in acidity $(\mathrm{pH})$ with increasing depth through each peat profile was also recorded. We observed a positive correlation between the $\mathrm{pH}$ and chemical composition of deposits, where a significant presence of calcite is associated with higher reaction (higher $\mathrm{pH}$ ), whilst a lower $\mathrm{pH}$ is characteristic for sediments where carbonates are rare. The recognized species of mollusks are typical of shallow, fresh-water stagnant reservoirs with a high fluctuation of water level.
\end{abstract}

Key words: peat, mineralogy, scanning electron microscope (SEM), pH, total sulphur (TS), carbon content (CC)

\section{Introduction}

Peat swamps are recognized as important biogenic, geological deposits, formed through sedimentary processes (Borówka et al., 2014). The formation of peat deposits is characterized by a lack of oxygen and highly hydrated conditions, and such environmental conditions contribute to plant decomposition and afterwards to various biochemical changes within the deposit. Depending on the hydrological conditions of peat bogs, biogenic deposits can be characterized by a diverse lithogeochemistry (Domińczak and Okupny, 2010). Organic matter sedimentation is driven by processes such as an increase in supply of allochthonous mineral matter and adsorption of dissolved water ions by clay minerals, which contribute to the chemical composition of organic sediments (Borówka, 2007). The chemical composition of peat organic matter is characterized by a complex mixture of organic compounds, which may include organic acids and their salts, bitumens, cellulose, lignins and proteins (Tobolski, 2000). All of these organic compounds undergo biochemical 
transformations, which may lead to the formation of calcium carbonate $\left(\mathrm{CaCO}_{3}\right), \mathrm{Fe}$ rich carbonates $\left(\mathrm{FeCO}_{3}\right)$, and iron hydroxides (FeOOH, meadow ore). Organic matter decomposition often takes place in anaerobic conditions, where released hydrogen sulphide enables the precipitation of iron sulphides $\left(\mathrm{FeS}, \mathrm{FeS}_{2}\right)$. Biogenic sediments that form in continuously or periodically wet environments show changes in redox features. This is seen in wetland environments as periods of variation in iron and manganese reduction (Marcinek and Komisarek, 2011). In addition to the occurrence of other chemical compounds (e.g. secondary carbonates) in biogenic sediments, the hydrological regime and geological setting of the peat bog area are important. These factors affect peat type, decomposition rate, and the intensity and direction of transformations, which take place within these deposits (Ilnicki, 2002).

This study focuses on the mineralogy of the studied peats which is considered a product of various reactions, and depend on several factors, with depth, $\mathrm{pH}$, non-organic sulfur and carbon content, lithology, and water content being the most important.

\section{Material and methods}

\section{Study area}

We studied peat bog profiles from Kietrz $\left(50^{\circ} 04^{\prime} 37.2^{\prime \prime} \mathrm{N}, 18^{\circ} 02^{\prime} 44^{\prime \prime} \mathrm{E}\right)$, located in southern Poland, within the meso-region of the Głubczycki Plateau, formerly of the Silesia Lowland macroregion (Fig. 1). The area of peat bog lies within a region of the Głubczycki

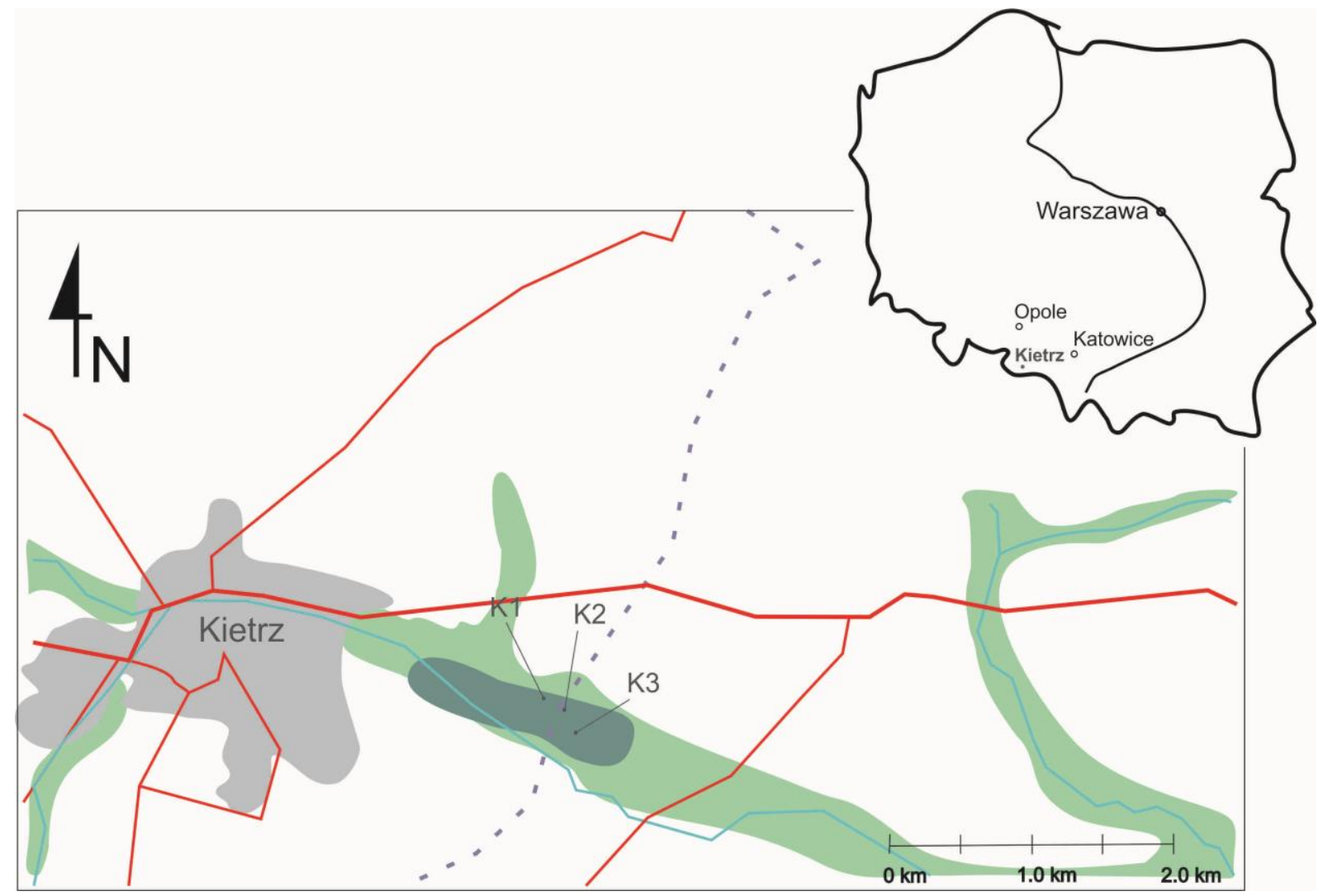

Fig.1. Location of studied peatland in Kietrz site, southern Poland. Source: Author's compilation 
High Plain, where the following two secondary regional units can be distinguished: the Grab Suchej Psiny (Trzepla, 1997), a feature that rises tens of meters above surrounding valleys, with a loess cover at its apical part; the Depression of Troi comprising wide river valley, cut into a loessal high plain. The peat bog in Kietrz and others occurring in this area belong to peat bogs of Moravian Gate valley/area.

\section{Sampling}

Peat profiles were collected in 2014 from three zones of the Kietrz peat bog, consecutively $\mathrm{K} 1(1.95 \mathrm{~m}), \mathrm{K} 2(3.50 \mathrm{~m})$ and $\mathrm{K} 3(3.60 \mathrm{~m})$. For this study 10 samples were investigated for profile $\mathrm{K} 1$, and 20 samples each for $\mathrm{K} 2$ and $\mathrm{K} 3$ profiles. Instorf (Eijkelkamp) probe was used for sample collection until the following monoliths were encountered: 14 single monoliths $0.05 \mathrm{~m} \times 0.5$ $\mathrm{m}$ and one $0.05 \mathrm{~m} \times 0.4 \mathrm{~m}$. Profile $\mathrm{K} 1$ was located in a marginal section of the peat bog, and profiles $\mathrm{K} 2$ and $\mathrm{K} 3$ were located towards its central section (Fig. 1). The peat bog is covered by a soil layer up to $0.6 \mathrm{~m}$ thick and is situated within an agricultural area adjacent to the forest. According to the nomenclature of System of Spatial Information (geographic information system) regarding swamps in Poland (GIS Swamps), provided by The Institute for Land Reclamation and Grassland Farming in Falenty, the peat bog in Kietrz was assigned the number 4826009AB. It is characterized as a peat bog of the lowland type with interlayers of a high and transitional type, and with marked lacustrine phases. This kind of peat bog was further defined as bulrushmineral.

\section{Methods}

The mineralogy of samples $\mathrm{K} 1, \mathrm{~K} 2$, and $\mathrm{K} 3$ were investigated using a Philips XL30 Environmental Scanning Electron Microscope
(ESEM) with an EDAX analyzer. The analyses were carried out in a low-pressure mode ( 0.3 Torr). The acceleration voltage was $15 \mathrm{kV}$. Back Scattered Electron (BSE) images were collected using a Centaurus attachment with a detector resolution of $0.3 \mathrm{Z}$. EDS spectra were analysed using Philips software.

Prior to analysis peat was air-dried and desiccated for one hour at $75^{\circ} \mathrm{C}$. Samples were mounted on carbon tape placed on an aluminium plate. 110 images were taken.

The total sulphur (TS) content and carbonate content (CC) were determined using an ELTRA CS-500 analyzer. Before the analysis, moisture was removed by drying the samples for 24 hours at $50^{\circ} \mathrm{C}$.

After samples were dried for 5 days in $50^{\circ} \mathrm{C}$, soil acidity was measured with an Elmetron $\mathrm{CP}-401 \mathrm{pH}$ meter. Dried material was ground using an agate mortar and 20 grams of peat were taken from each sample.

\section{Results}

Scanning Electron Microscope (SEM) equipped with EDS

\section{Gypsum}

The most common mineral in all samples is gypsum $\left(\mathrm{CaSO}_{4} \times 2 \mathrm{H}_{2} \mathrm{O}\right)$. It forms crystals of various in sizes, ranging from 1-2 $\mathrm{mm}$ long (Fig. 2). Gypsum occurs as flattened and often twinned crystals (swallowtail). Many build rose-type aggregates (Fig. 2E).

\section{Pyrite}

The most abundant form of sulphate in all studied samples is pyrite $\left(\mathrm{FeS}_{2}\right)$. It forms crystals ranging in size from a few microns up to $30 \mu \mathrm{m}$ in diameter (Fig. $3 \quad$ A-D). Occasionally, euhedral (octahedral) pyrite crystals 10-12 $\mu \mathrm{m}$ are present (Fig. 3C). Pyrite was observed in all but one layer (1.30-1.45 m) of the K2 profile (Fig. 7.). 


\section{Fe-rich oxides/hydroxyl-oxides}

Fe-rich oxides/hydroxyl-oxides occur as independent grains, varying in size from a few microns up to $30 \mu \mathrm{m}$. In some cases, Fe-rich hydroxyl-oxides appear as massive forms enclosing other minerals (e.g. gypsum; Fig. 3E-F), and as overgrowths on pyrite, or surrounding small plant fossils. A patchy structure on BSE images reflects the varying iron contents (Fig. 3D). Single automorphic crystals of oxides/hydroxyl-oxides were not found.

\section{Carbonates}

Carbonate content is limited to Ca-rich carbonate (calcite; $\mathrm{CaCO}_{3}$; Fig. 4A-B). The calcite crystals range from 200-250 $\mu \mathrm{m}$. Carbonates are found throughout the three studied profiles. A $15 \mathrm{~cm}$ long interval in the $\mathrm{K} 1$ profile, from $1.30 \mathrm{~m}$ to $1.45 \mathrm{~m}$, is rich only in carbonates (Fig. 2). A few examples of small Ca-rich carbonate fragments were found (Fig. 4C), which probably are the fragments of reworked and crushed Mollusca shells (Fig. 4D).

\section{5. $K$-feldspar}

In the deepest part (3.1-3.55 m) of the K3 profile, fragments of $\mathrm{K}$-feldspars were found. They are up to $10 \mu \mathrm{m}$ long (Fig. 4E) and the EDS spectrum confirmed their composition as most likely representative of orthoclase or microcline feldspars (Fig. 4F).

\section{Clay minerals}

Clay minerals commonly coat the other mineral phases and/or plant remains in the peats (Fig. 5A-B). They are not long or thick enough to obtain a clear EDS spectrum due to background interference from the signal of other elements (Fig. 5E).

\section{Quartz}

Quartz, the most common light-mineral phase, is almost in all cases well rounded (Fig.
5C, E) with grains varying in size from $\sim 50$ $\mu \mathrm{m}$ to $\sim 450 \mu \mathrm{m}$ (fraction of very fine sand).

\section{Zircon}

Zircon (Zr) crystals in the studied peat samples are rare-and relatively small. They are not present in profiles K1 and K2 (Figs. 6 and 7 ) and were only found in one layer of the K3 profile (Fig. 8). Two zircon crystals measure $>10 \mu \mathrm{m}$ long, but only one crystal shows a fragmentary sharp bi-pyramidal form with an aspect ratio of 5:2 (Fig. 5D, F).

\section{Apatite}

Based on EDS analyses of 5 apatite fragments, all investigated apatites may be classified as fluoroapatite. The apatite grains range from $0.05 \mathrm{~mm}-0.1 \mathrm{~mm}$ in length and from $0.05 \mathrm{~mm}-0.15 \mathrm{~mm}$ in width (Fig. $5 \mathrm{~A}$, E).

\section{pH results}

The investigated peat sediments are neutral to lightly alkaline. With increasing depth peat reaction moves towards the middle-acidic range. Only in profile K3 (Fig. 8) sample \#4 $(2.85 \mathrm{~m})$ is $\mathrm{pH}$ highly acidic. In profile $\mathrm{K} 1$ (Fig. 6) pH contents level vary from 5.31-7.46 $\left(\mathrm{pH}_{\mathrm{H} 2 \mathrm{O}}\right)$ and $4.90-7.23\left(\mathrm{pH}_{\mathrm{KCl}}\right)$. In profile $\mathrm{K} 2$ (Fig.7.) $\mathrm{pH}$ varies from 6.41 to $7.56\left(\mathrm{pH}_{\mathrm{H} 2 \mathrm{O}}\right)$ and from $6.21-7.41\left(\mathrm{pH}_{\mathrm{KCl}}\right)$. In contrast, in a point $\mathrm{K} 2$ of profile $\mathrm{K} 3$ (Fig. 8.) reaction varies from 1.88 to $7.49\left(\mathrm{pH}_{\mathrm{H} 2 \mathrm{O}}\right)$ and 1.79-7.16 $\left(\mathrm{pH}_{\mathrm{KCl}}\right)$.

The total sulphur (TS) and carbonate (CC) contents

Preliminary results of TS and CC show differing values. The $\mathrm{K} 1$ profile (Fig. 6) is characterized by TS and CC content in the range $0.94-2.74 \%$ and $0.00-66.41 \%$, respectively. In the next profile (K2; Fig. 7) TS is on average $5.18 \%$, but a single sample sample at $2.05 \mathrm{~m}$ shows significantly higher 
TS content $(\sim 22 \%)$ compared with other samples in profile. CC content in this profile is ranges from $0 \%$ to $84.13 \%$. The $\mathrm{K} 3$ profile (Fig. 8) shows increasing TS content with depth, reaching a maximum of $13.99 \%$. The
CC content shows a wide range of values, similar to the $\mathrm{K} 2$ profile. There are horizons where the $\mathrm{CC}$ content is as low as $0.1 \%$, but in others the CC is up to $\sim 68 \%$.

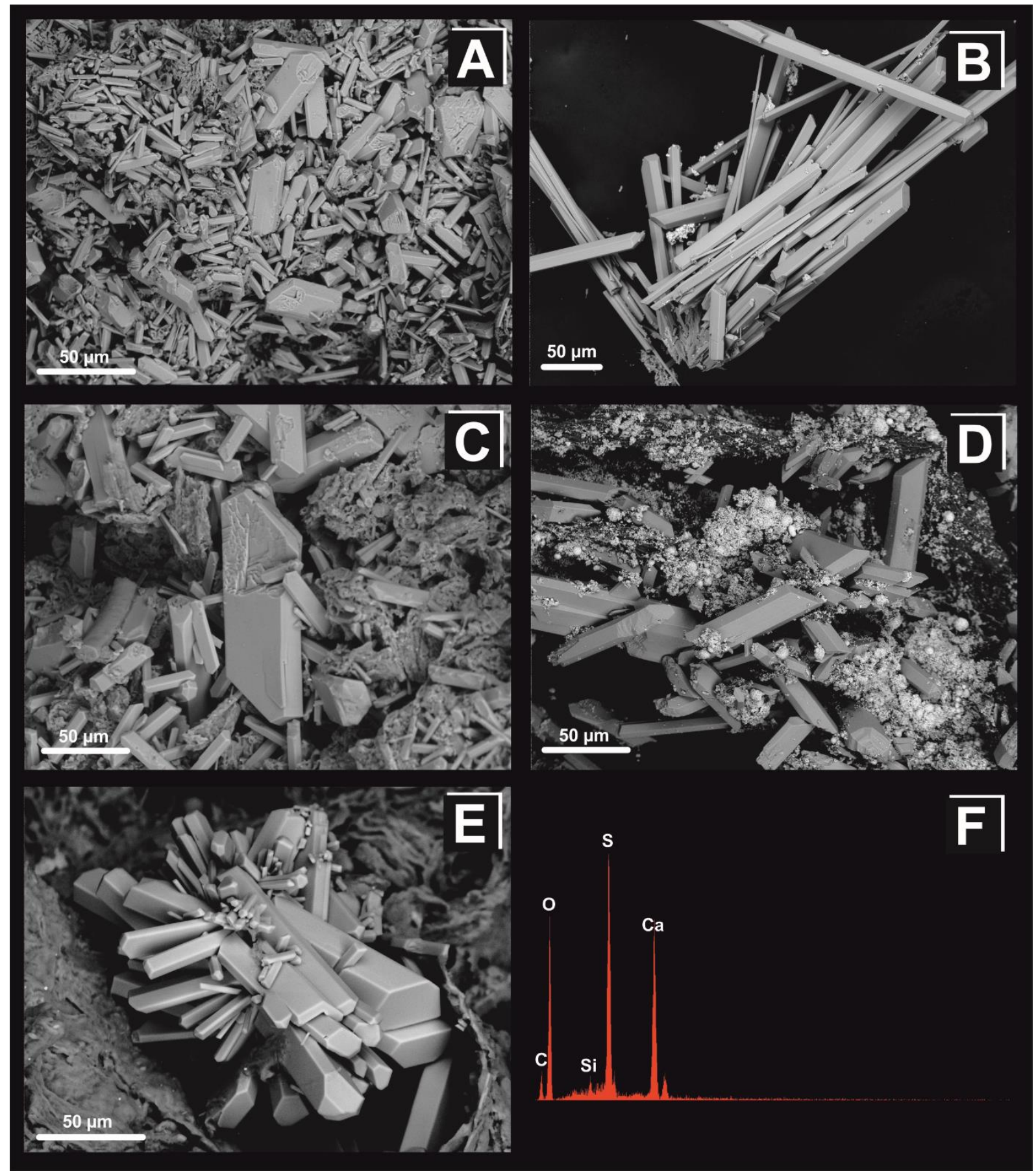

Fig.2. BSE images showing habits of gypsum crystals from peats at the Kietrz site. (A) An example of the most common type of the crystals. (B) Some crystals are strongly elongated. (C) Rarely, in some cases the crystals are partially dissolved. (D) Gypsum crystal are often associated with pyrite framboids. (E) Commonly rose-type gypsum crystals are noted. (F) A typical EDS spectrum of gypsum. 


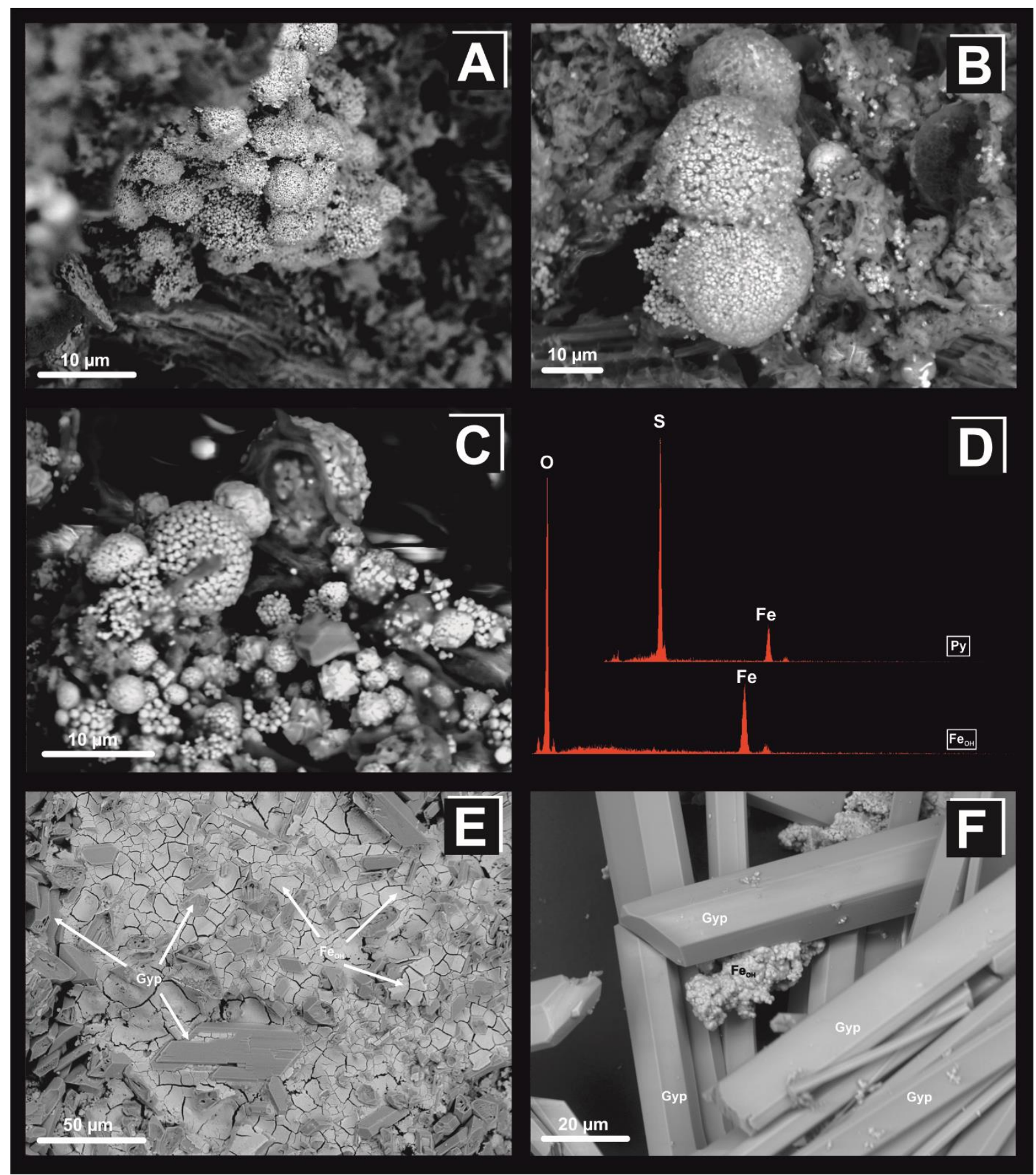

Fig.3. BSE image of pyrite and Fe-rich hydroxyl-oxides from the peats at the Kietrz site. The most common form of pyrite are framboids (A-B) which occasionally form bigger cubic crystals (C). An example of typical EDS spectrum of pyrite (Py) and Fe-rich hydroxyl-oxides (FeOX) (D). Fe-rich hydroxyl-oxides are often associated with gypsum (E) as a mass enclosing the sulphates or forming aggregates on the crystals $(\mathrm{F})$. 


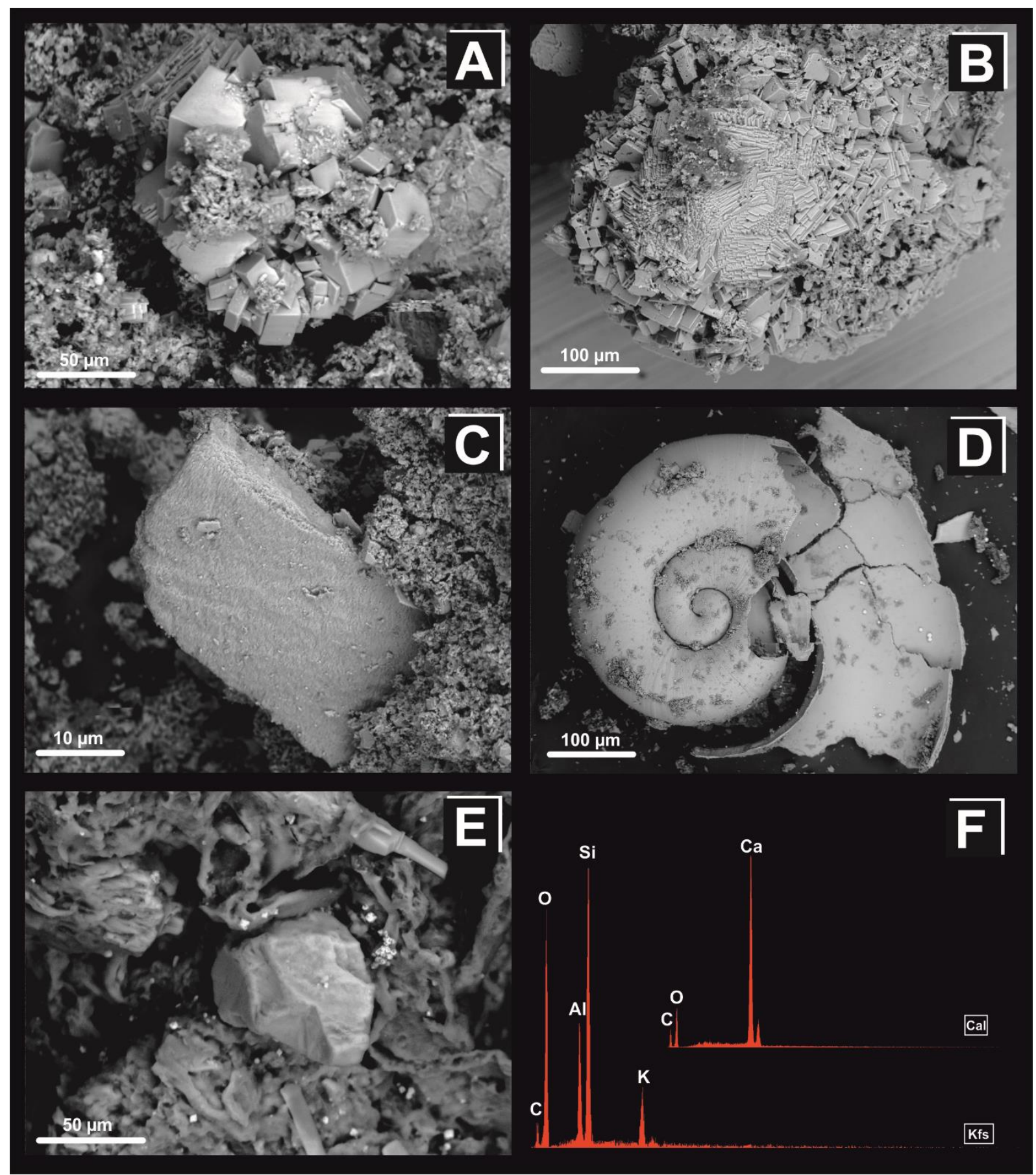

Fig.4. BSE image of calcium carbonate (calcite) (A-B), and fragmentary Mollusca shell (C-D) as well as finegrained K-feldspar (E) from the investigated peats at the Kietrz site. A typical EDS spectrum of K-feldspar (Kfs) and $(\mathrm{F})$ calcium carbonate $(\mathrm{Cal})$. 


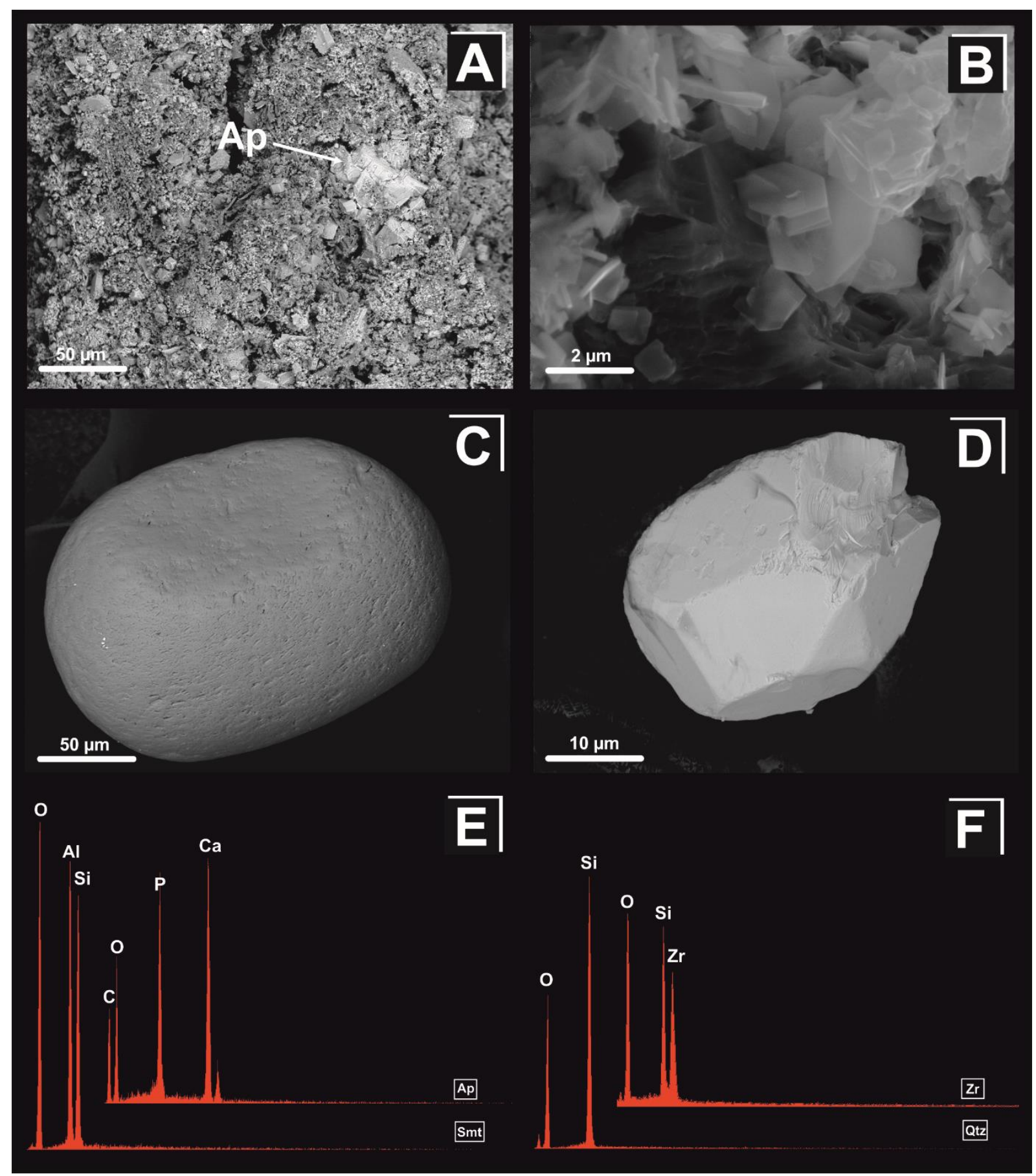

Fig.5. BSE images of rare accessory minerals found in the peats at the Kietrz Site. (A) An example of clay minerals and apatite (Ap) (B) apatite xenomorphic in shape, (C) an example of rounded quartz grain, (D) single, near-automorphic zircon crystal, (E) a typical EDS spectrum of clay minerals (Sm), apatite (Ap), (F) quartz (Qtz) and zircon (Zr). 

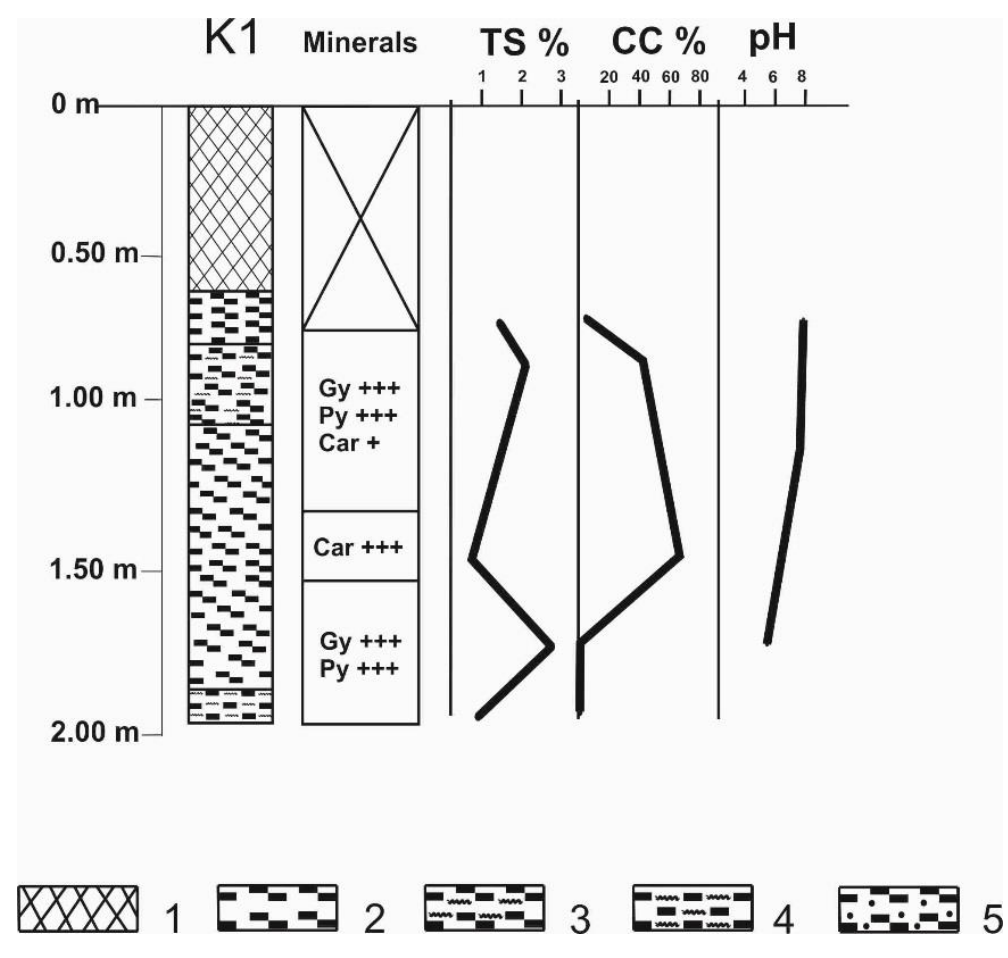

Fig.6. Relationship between lithology and contents of total sulfur (TS), total carbonate (CC), and $\mathrm{pH}_{\mathrm{H} 2 \mathrm{O}}$ level for samples in profile K1 ( the Kietrz site). Core lithology: 1 - mineral deposits, 2 - organic deposits, 3 - organic deposit mixed with mud, 4 - mud with organic matter, 5 - organic deposit mixed with sands. Give the number to each sample in the profile on figure and reference it in text.

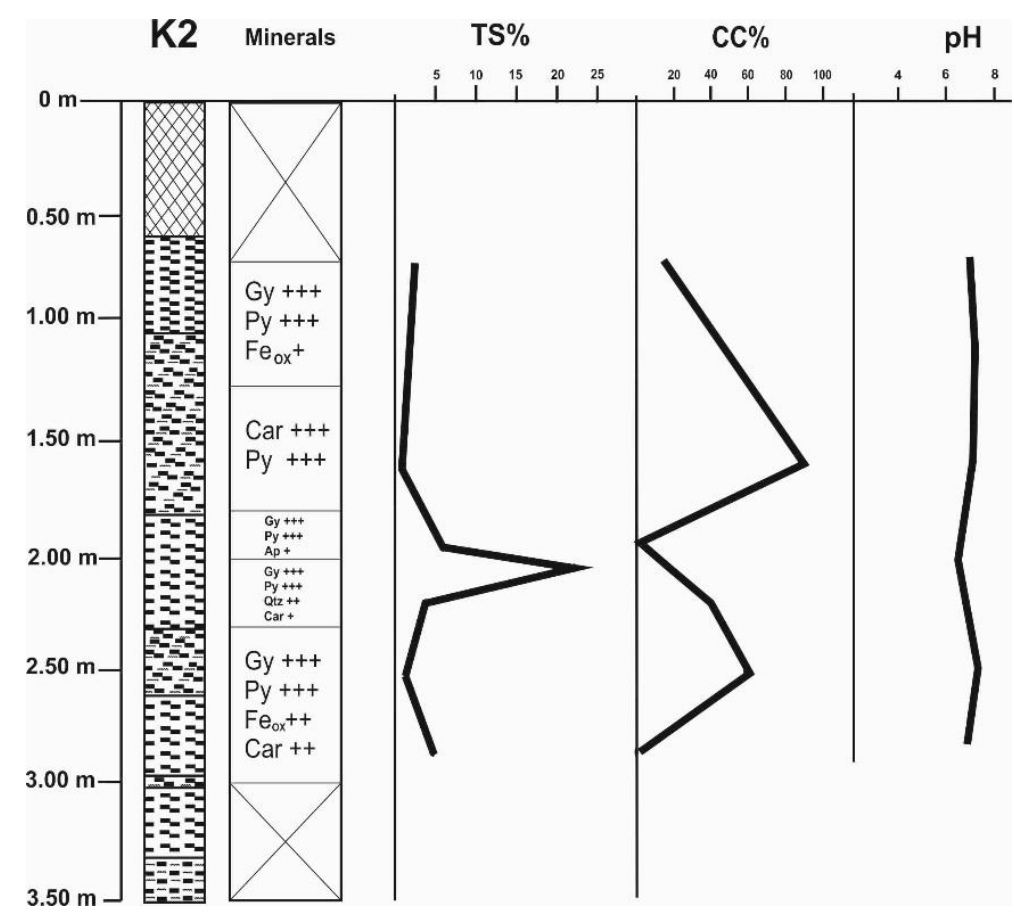

Fig.7. Relationship between lithology and same as above content, $\mathrm{pH}_{\mathrm{H} 2 \mathrm{O}}$ from profile $\mathrm{K} 2$ (the Kietrz site). The legend as on figure 6 . 


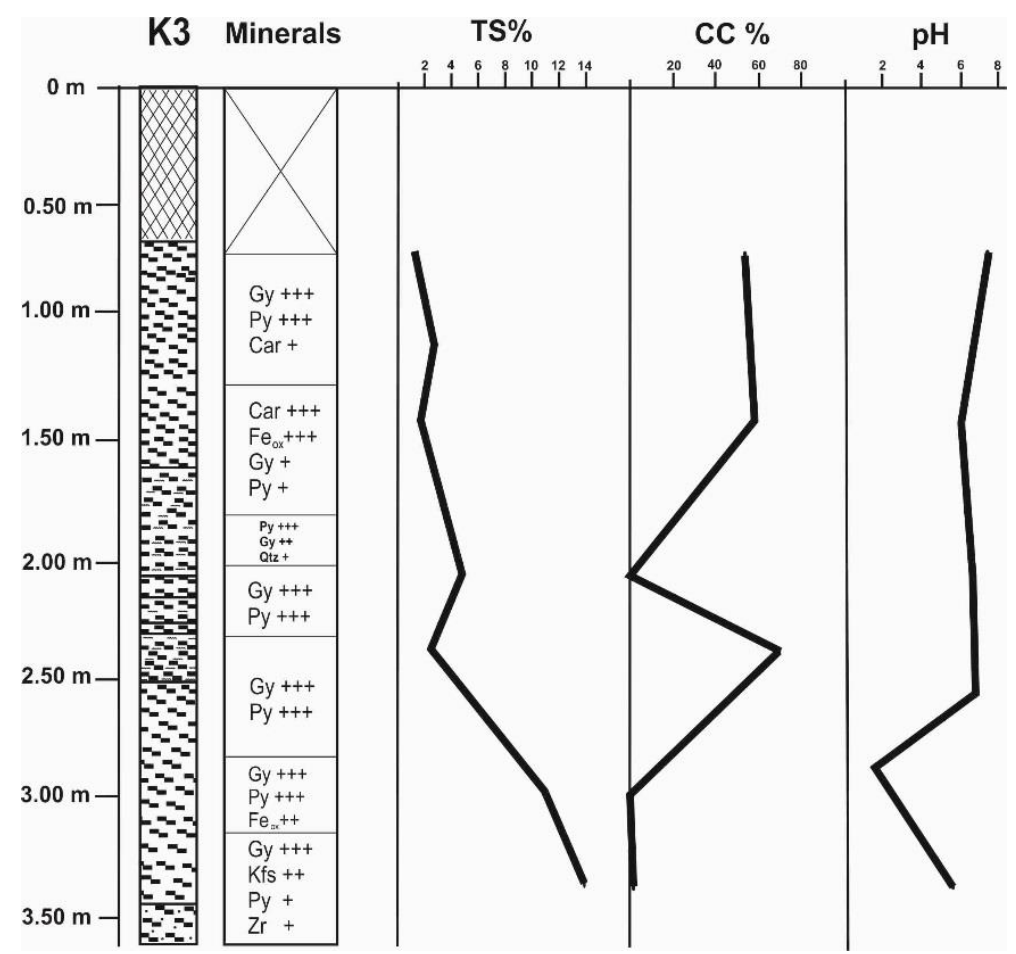

Fig.8. Relationship between lithology and same as above content, $\mathrm{pH}_{\mathrm{H} 2 \mathrm{O}}$ from profile $\mathrm{K} 3$ (the Kietrz site). The legend as on figure 6.

\section{Discussion}

In the studied peat samples, two different groups of mineral phases were distinguished: a primary "authigenic" mineral phase, with pyrite and carbonates, and a secondary mineral phase comprising gypsum, Fe-rich oxides/hydroxyl-oxides, which are products of oxidation/weathering of the primary minerals. The mineral suites and their distribution throughout the studied profiles, when compared with changing $\mathrm{pH}$, TS, and $\mathrm{CC}$ point to differing changes in chemistry and mineralogy.

In the profile $\mathrm{K} 1$, three levels of gypsum and pyrite enrichment were noted. In these levels gypsum and pyrite occur up to 20 vol. $\%$. In the lowermost and uppermost parts of this profile there are spherical aggregates of framboidal pyrites, composed of densely packed $\mathrm{FeS}_{2}$ crystals, varying in size from a few microns up to $30 \mu \mathrm{m}$, and surrounded by tabular crystals of gypsum with maximum length of $500 \mu \mathrm{m}$. Present also are twinned, swallowtail-form gypsum crystals. In the K1 profile calcite was found at all levels except one (Fig. 6). The characteristic feature of the $\mathrm{K} 1$ profile is the depleted TS content in the middle of the profile, where instead $\mathrm{CC}$ content is enriched (Fig. 6).

The $\mathrm{K} 2$ profile is mainly characterized by the presence of gypsum and pyrite, with calcite at certain horizons, as well as with small amounts of quartz and Fe-rich oxides/hydroxides. In the $\mathrm{K} 2$ sample abundant in framboidal pyrite $(5-20 \mu \mathrm{m})$ is seen. Pyrites (Fig. 7) occurred in the vicinity of calcium carbonates, tabular in habit, and ranging in size from $2 \mu \mathrm{m}$ to $50 \mu \mathrm{m}$ (Fig. 7). The largest calcite content in profile $\mathrm{K} 2$ is found at a depth interval from $1.3 \mathrm{~m}-1.6 \mathrm{~m}$. Iron oxides and hydroxides, gypsum and apatite were rare (Fig. 7). Very often in the studied profile regular grains of quartz $(100 \mu \mathrm{m}-450 \mu \mathrm{m})$ were present, especially in deeper part, above 1.90 $\mathrm{m}$ (Fig. 7). The TS and CC contents vary throughout the profile. The largest concentrations of TS were found at a depths of $2.05 \mathrm{~m}-2.30 \mathrm{~m}$ and record the highest value of TS from all three studied profiles. The CC 
content varies also, but at $1.90 \mathrm{~m}$ the $\mathrm{CC}$ content was not measurable.

In the lower part of the K3 profile potassium feldspars were noted as well-formed tabular crystals of gypsum up to $350 \mu \mathrm{m}$ (Fig. 8). Numerous framboids of iron sulphides up to $50 \mu \mathrm{m}$ also occur. These minerals are present at the following depths: $1.3 \mathrm{~m}, 2.0-2.2$ $\mathrm{m}, 2.55 \mathrm{~m}$, and $3.30 \mathrm{~m}$. Grains of quartz, iron oxides/hydroxides and potassium feldspars were rarely identified (Fig. 8). Calcite was identified at $1.45-1.75 \mathrm{~m}$ and $2.25-2.40 \mathrm{~m}$, as tabular crystals ranging from $5 \mu \mathrm{m}$ to $200 \mu \mathrm{m}$ (Fig. 8). In this profile, near-complete and fragmentary mollusk shells and plant fragments are noted. Four samples from the K3 profile are characterized by very low $\mathrm{CC}$ content, that is up to $0.31 \%$. TS content increases with depth (Fig. 8).

Preliminary macro-remains analysis helps to distinguish several peat types, representing sedge-moss peat, sedge-reed peat, moss-sedge peat and reed peat decomposed to a various degree. Moreover, levels with organiccarbonate, organic-mineral and mineral sediments were all defined. All sediments representing the studied profiles from the Kietrz site are enriched in freshwater fauna remains (Mollusca, Cladocera).

\section{Conclusions}

Preliminary documentation of chemical diversity of biogenic sediments at the Kietrz site was determined by variable sedentation conditions, which resulted in deposition of different types of peats. The factors partially responsible for chemical implications of the peats are geological settings and lithology of the area during peat formation.

Secondary mineral formation occurred due to chemical changes of the ground water supply connected with the peat ecosystem. Dissolution and participation of mineral phases rich in, e.g. $\mathrm{S}, \mathrm{C}, \mathrm{Ca}$, is the main process responsible for the $\mathrm{pH}$ changes in the investigated peat profiles. More detailed studies on this material should bring better characterization of organic and mineral matter evolution in the peat at this site.

\section{Acknowledgments}

We thank Prof. dr hab. Leszek Marynowski (University of Silesia, Katowice, Poland) for helpful discussion and Total Carbon and Carbonate Content analyses. Special thanks go also to Dr. Krzysztof Wójcicki (University of Silesia, Katowice, Poland) for may useful comments during the manuscript preparation. Careful reviews by Agnieszka Furmann and Tomasz Krzykawski improved the manuscript significantly.

\section{References}

Borówka R. K. (2007) Geochemiczne badania osadów jeziornych strefy umiarkowanej. Stud. Lim. et Tal. 1(1), 33-42

Borówka R.K, Tomkowiak J., Okupny D., Forysiak J. (2014) Chemical composition of biogenic sediments from the Ner river valley (Mianów peatland, Łask Elevation). Folia Quaternaria 82, 51-69, DOI: 10.1515/FOLQUART-2015-0003

Domińczak P., Okupny D. (2010) Spatial variability of selected physicochemical properties of biogenic sediments in the Kopanicha peatland near Skierniewice (in Polish with English summ.). Prace Geografi czne IGiGP 123: 99-110

Ilnicki P. (2002) Torfowiska i torf. Wydawnictwo Akademii Rolniczej im. Augusta Cieszkowskiego, Poznań, 432-433

Lewandowski J. (2003) Plejstocen glacjalny Kotliny Raciborsko-Oświęcimskiej o obszarów sąsiednich. Pages: 16-28. In: Plejstocen Kotliny RaciborskoOświęcimskiej na tle struktur morfologicznych podłoża czwartorzędu. Eds. J. Haisiga and J. Lewandowski. PIG, Sosnowiec 2013. (in Polish) 
Tobolski K. (2000) Przewodnik do oznaczania torfów i osadów jeziornych. Wydawnictwo Naukowe PWN, Warszawa, 83-87
Trzepla M. (1997) Szczegółowa Mapa Geologiczna Polski w skali 1:50 000, arkusz Racibórz 